\title{
The Effect of Authentic Leadership on Organizational Communication: The Mediating Role of Psychological Well-Being
}

Article History:

Received 05.05.2021

Received in revised form

04.12.2021

Accepted

Available online 01.03.2022

\author{
Gülsu Naiboğlu ${ }^{1}$, Orkun Osman Bilgivar ${ }^{2}$
}

\begin{abstract}
The purpose of this research is to determine the mediating role of psychological well-being in the effect of authentic leadership on organizational communication. For this purpose, the opinions of 439 teachers working in Istanbul in the 2020-2021 academicyear were consulted. Hypotheses related to the model, which was created based on the theoretical framework, were tested by establishing the research. In the research, "correlation design," one of the quantitative research designs, was used, and Baron and Kenny's four-stage model was used to create and test the model. "Authentic Leadership Scale," "Communication Competence Scale," and "Psychological Well-Being Scale" were applied to the participants in the study. As a result of the research, it was found that authenticleadershiphighly affects organizational communication; It has been determined that psychological well-being has a partial mediating role in the significant positive effect of authentic leadership on organizational communication. In the research, according to the gender of the teachers, in the opinions of school administrators on communication competencies; shows that male teachers are higher than female teachers. In the research, according to the educational status of the teachers, the psychological wellbeing of undergraduate teachers was lower than that of graduate teachers. The most striking finding of the study is that authentic leadership highly affects organizational communication.
\end{abstract}

(C) IJERE. All rights reserved

Keywords: Authentic leadership, organizational communication, psychological well-being, educational organizations

\section{INTRODUCTION}

Although many definitions have been proposed for 'leadership' which all have the common feature of directing, facilitating, structuring, organizing and influencing all the work done towards the purpose of an organization, no clear definition has been reached by social scientists, even today. Recent studies have determined that leadership involves "a life-long process" and "learnable/improvable and unique" features and characteristics (Aksoy, 2020; Maxwell, 2020; Yukl, 2018; Zel, 2011). Leadership as a concept has developed along several different approaches according to its various characteristics: in the characteristics approach, it is the characteristics of the leader which are explored; the behaviors exhibited by the leader are the focus in the behavioral approach and in the situational approach the attitudes of the leader in different situations are investigated. Today, with the modern/contemporary approaches, the reasons for a leader's behavior have started to be investigated and different leadership characteristics have been identified by considering the leader holistically (Yetgin, 2020). Different managerial needs point out the need to address the deficiencies of the previous approaches and the unanswered questions and inadequate aspects of modern approaches to leadership. The common feature of the current approaches is that "the relationship between the leader and his followers" comes to the fore. These approaches increase as new ones continue to emerge (Y1lmaz, 2020).

The changes brought about by globalization, the negativities in the world, the loss of trust in the leader, social resistance and a range of concerns have led people to seek different leadership styles and the recent increase in interest in positive psychology and authentic leadership which focuses more on the concepts of trust and ethics and on the essence of the human being, separate from the previous leadership - charismatic, transformational, servant and ethical - has been revealed. Based on and nourished by the foundations of positive psychology, authentic leadership is focused on the truth of the leader and is still in its developmental stage (Coşar et al., 2012; Northhouse, 2019; Oruç, 2020; Yukl, 2018). Authentic leadership m eans that the leader, who is also included in the content of positive psychology, has the characteristics of being "positive, sincere, reliable, transparent and self-assured". An authentic leader is someone who knows him/herself, has selfawareness, attaches importance to personal development, has moral values, acts without duplicity, has positive relations with followers, reveals the potentials of others like him/herself and is full of hope (Avolio $e t$ al., 2004; Akyürek, 2020). Authentic leadership expresses the interaction and positive communication between the leader and the followers and also emphasizes communication between the leader and the followers within an organization (Eagly, 2005). Understanding the communication in organizations that are communities which have come together to serve a specific purpose is a process in which members of the organization mutually "value their ideas, feelings, and behaviors, try to understand, and exchange information and thoughts" (Etzioni, 1964, as cited in Aziz \& Dicle, 2017). If there is no exchange of information and ideas among the 
members of an organization, the existence of the organization becomes untenable: this communicative relationship includes understanding; that is, that both parties can see the same picture. Communication is a force for "control, motivation, interaction and knowledge transfer" within an organization (Robbins \& Judge, 2019). Interpersonal communication can be effective if it consists of openness, empathy (feeling what others are feeling), support (accepting), positivity and similarity (Tampubolon \& Harati, 2019). Healthy communication within an organization is an expression of managerial power. Depending on this power, the organization shows efficiency and sustainability and has the key to success. In this regard, leaders must give their followers confidence, make clear, precise and accurate transfers, and in the same way, their followers must exhibit the same attitude towards their leader. The more open, honest and reliable the communication between the leader and the followers is, the easier it will be for the organization's success and goal to be achieved (Gülver, 2014). Authentic leadership, unlike other leadership approaches, is based on more positive values, self-awareness and a relationship of trust with followers (Yukl, 2018). Transparency in relationships is one of the dimensions of authentic leadership; it means that the leader's sincerity, trustworthiness and honesty towards the followers are at the highest level and it means sharing openly in all aspects of the organizational endeavor, exhibiting clear behavior and expecting the same transparency from the followers (Luthans et al., 2007; Gardner et al., 2005).

Positive psychology is a scientific field which forms the basis of authentic leadership. It focuses on searching for meaning, positive and virtuous aspects, strengths and the development of human beings (Peterson, 2006; Seligman \& Csikszentmikalyi, 2000); it is a balancing act which focuses on developing the strengths of individuals and of communities (Göçen, 2019; Hefferon \& Boniwell, 2018). It includes the experiences of the past (well-being and satisfaction), the present (hope and optimism) and the future (flow and happiness) in the individual, and in terms of individuality, it includes "love and professional capacity, courage, interpersonal skill, aesthetic sensitivity, perseverance, forgiveness, originality. It is about futuremindedness, spirituality, high talent and wisdom". The organizational field is about correct orientation such as "responsibility, care, altruism, kindness, moderation, tolerance and business ethics" (Seligman \& Csikszentmihalyi, 2000). The main purpose of positive psychology is to seek answers to questions about the positive traits which feel good and which of our strengths cause us to act (Iş1k, 2020). The concept of 'psychological well-being' in human beings includes "the individual realizing her/his potential, knowing herself/himself and accepting herself/himself as she/he is, establishing good relations with positive thinking and having a purpose in life" (Keyes et al., 2002). Psychological well-being has an important role in individuals' working lives and organizations, and previous studies have supported this (Demirci \& Şar, 2017).

Studies have shown that authentic leadership comprises several different variables: the relationship between authentic leadership and psychological capital (Soylu, 2018), between authentic leadership and organizational commitment (Yaşbay, 2011); between authentic leadership and job satisfaction (Uslu, 2017) and the mediating role of psychological capital in the relationship between authentic leadership and organizational commitment (Büyükbeşe et al., 2019). The purpose of the current study is to determine the effect of authentic leadership on organizational communication and the mediating role of psychological well-being in this effect. The distinguishing feature of this study from other studies is that these three variables have not been studied together in the previous literature.

\section{Authentic Leadership}

Authentic leadership, which focuses on the reality and truth of leadership, is based on the word authenticity whose roots go back to Aristotle and Plato. Authenticity is the commitment to "the individual's core values, feelings, personality traits" and "depending on his life experiences, showing his essence, that is, all his wishes, desires, feelings, priorities, beliefs" in his actions by knowing and accepting; authenticity symbolizes the "self-identity" of the individual (Korkmaz, 2017; Ladkin \& Spiller, 2013). Authentic leadership is based on positive psychology: for positive psychologists, authenticity means "reflecting one's self as one is"; behaving in accordance with one's essence, free from pretense and falsehood (Gardner et al., 2011; Goffee \& Jones, 2005). The authentic leadership approach is based on promoting openness, which is important for innovation and creativity, and building trust between the leader and the followers, basing the validity of the leaders on ethical and moral grounds, and establishing respectful and honest relationships with their followers (Elrehail et al., 2018). Luthans and Avolio (2003) used the concept of originality by integrating positive psychology with existing leadership theories and drew profiles of leaders as "confident, hopeful, optimistic 
and resilient" (Sparrowe, 2005). Authentic leadership is a developmental leadership model which develops self-awareness in the leader and frames a process for his followers which makes use of positive capacities in the organization, positive personal development, is happy, confident, optimistic and transparent, attaches importance to the development of his followers, is loyal and sets a model for his followers through his core values, beliefs and behaviors (Luthans \& Avolio, 2003). Because authentic leaders do not act selfishly and are not 'me-centric', a positive atmosphere is created within the organization, and thus the goals, mission and vision of the organization can be achieved successfully (Baykal, 2017).

Authentic leadership has many different definitions. Shamir and Eilam (2005) considered authentic leadership to be an "inner perspective" and defined authentic leaders as having "self-knowledge, selfregulation, self-concept, away from copying, developing by knowing their own experiences". Eagly (2005) considered authentic leadership to be an "interpersonal process" and emphasized the relationship and interaction between leader and follower. Avolio and Gardner (2005) and Gardner et al. (2005) defined authentic leadership as a process which can develop throughout life and whose course can change with lived events with a "developmental perspective". The theoretical perspective on which this current study is based is authentic leadership as defined by Walumbwa et al. (2008). Walumbwa et al. (2008) studied authentic leadership extensively: they regarded it as a form of leadership which has positive psychological qualities and an enhanced moral sense and which reflects these in the leader's behavior. In this context, they identified four components of authentic leadership: self-awareness, an internalized moral perspective, balanced action and relational transparency (Northouse, 2018). These four components were the basis of the Authentic Leadership Questionnaire developed by Walumbwa et al.(2008) which was used in the current study (Gardner et al., 2011).

\section{The Components of Authentic Leadership}

Self awareness: the Ancient Greek maxim 'Know thyself' refers to the importance of self-knowledge in all aspects; being aware of all your strengths and weaknesses, knowing your needs, desires, wishes, values and beliefs, being honest with yourself and acting primarily with these components as they are, and being empathetic to others. Individuals with high self-awareness are aware of how their emotions affect them and others, have high self-confidence, can evaluate themselves realistically, accept their mistakes and exhibit objective behaviors according to their own beliefs and values (Goleman, 2004; Yaşbay, 2011; Yılmaz, 2020). Self-awareness includes the ability to distinguish an event or process from others, perceiving and knowing the necessity of awareness and turning it into behavior, and enables leaders to recognize themselves in all aspects and take firm and decisive steps (Cüceloğlu, 2021a; Gardner et al., 2005).

Internalized moral perspective: this means self-regulation, which includes an individual's behavior consistent with his/her moral understanding, values and beliefs and guides the followers. It aligns with the leader's activities, beliefs and moral values, expressing self-worth before wanting to be liked by someone else (Northouse, 2018; Walumbwa et al., 2008). Leaders give confidence to their followers by making decisions in line with ethical standards (Karadağ \& Öztekin-Bayır, 2018).

Balanced Transaction: leaders make evaluations on the principle of impartiality. They analyse and understand data accurately by making objective, transparent and fair analyses during the decision stages. By acting honestly, they manage the process without distorting, exaggerating or ignoring. They are as close to the perspectives of others as to their own. Such leaders make decisions for the benefit of the organization and its members (Avolio \& Gardner, 2005; Coşar et al., 2012; Northouse, 2018; Walumbwa et al., 2010).

Relational Transparency: this means that the individual is open, clear and honest with other people and does not hesitate to show his/her positive and negative sides, reflecting reality in communication. Establishing transparent communication ensures trust between the leader and the followers and achieving the goal in a healthy way. Relationships which work with sincerity can establish relationships far from falsehood by both sides knowing what is positive or negative about each other. Leaders take part in the organization with their real identity (Coşar et al., 2012; Gardner et al., 2005; Kernis, 2003; Walumbwa et al., 2008). Authentic leaders act with self-awareness, trust-based, open and transparent communication, and sharing (Robbins \& Judge, 2019). 
The purpose of communication is to be understood and understanding between individuals involves the sharing of any feelings, ideas or information; verbal, written or non-verbal, positive or negative effects, which can be one-way, two-way or more, including diversity; it is a tool for the interaction within communities consisting of individuals and distinguishes humans from other living things and reveals their superiority; it is a process which surrounds us in every aspect of our lives and will continue throughout our lives (Aziz \& Dicle, 2017; Ertekin, 2017; Robbins \& Judge, 2019; Zillığlu, 2014). As soon as people notice each other, they communicate; not only words but also facial expressions, stance and gaze all have a meaning and people are in constant communication in their life adventures (Cüceloğlu, 2021b). Individuals need communication when presenting themselves, working with others, and ensuring work within an organization (Ertekin, 2017). Communication is a situation in which all individuals live and cannot escape in every area of life and in various ways because people live and work in society, in various organizations; in short, they socialize (Z1llığlu, 2014). Communication has exactly the same function within an organization. In line with the goals and objectives of the organization, its members are in a continuous process of sharing under the principle of cooperation. This sharing occurs and progresses with the power of communication. When the management approach is genuinely human-oriented, communication comes to the forefront by taking on a more sensitive aspect. Organizations unite for specific goals, and this unity enables the goals to be reached more accurately and easily through the robustness of communication. The fact that people are the main element of any organization necessitates communication as the principal activity (Eskiyörük, 2015). The existence of organizations also depends on this communication, on the exchange of messages. The effective functioning of the communication process means that the leader establishes problem-free and correct communication with his/her followers. As a result, the success of the organization is inevitable. Various factors can hinder communication, one of which is personal factors. Individuals' "emotions, values, habits, goals, trust, beliefs, attitudes" can cause different evaluations in sending and receiving messages between people (Koçel, 2018; Yildız, 2019). Bursalıoğlu (2019) considered this factor to be psychological and expressed it as the "difference of opinion, emotions, excitements, obsessions and personal concepts". Mutual personal differences and uncertainty between the leader and the followers will always be an obstacle to communication. Even though perfect communication is challenging, it is possible to reach near perfect. There is a positive relationship between the effectiveness of communication (perception of trust, accuracy, openness/transparency) and the productivity of organizational members (Robbins \& Judge, 2019). Communication plays an important part in every field of life, at every moment and in every organization, and educational organizations are no exception. Like every organization, educational organizations should have a correct communication network and policy which enable leaders and followers to achieve their goals. The most important factor affecting the healthy working of people in a social group is healthy communication (Güçlü, 2017). Educational organizations have a comprehensive organizational structure with administrators, teachers, students and parents. In this context, educational organizations reach their goals as a result of everyone working together. The good management of the organization is directly related to the leader, and the results of the leader's managerial style depend on his/her communication with the followers. The fact that communication is based on the principles of respect, trust and openness is at the top of the list of factors which will bring success. The integrity of an organization's 'nervous system' is maintained through communication (Ayeni \& Akınola, 2020). The communication of school principals with their teachers, as leaders, is also important because teachers are at the center of achieving the goals of schools (Ayeni \& Akinfolarin, 2014). An effective leader has the ability to successfully direct and mobilize all activities planned to achieve the organization's goals. Within the organization, the performance of the followers is affected by the communication with the leaders (Reza \& Nugroho, 2020). It has been accepted that one of the most important dimensions of communication is "to try to understand first and then to be understood". It therefore has an important place as a competence which leaders and followers should develop (Wijewantha, 2018).

\section{Psychological Well-Being}

Positive psychology, unlike the traditional psychology approach, is what constitutes people's success; it focuses on their strengths and positive aspects such as happiness and creativity. It seeks to focus on the reasons for people's happiness, productivity and well-being, rather than what lies behind people's negative thoughts and behaviors. Seligman and Csikszentmihalyi (2000) discussed the negative effects of concentrating on negativities and the importance of the development of individuals' strengths (Carr, 2016; Seligman \& Csikszentmihalyi, 2000; Uyar, 2019) and stated that "Well-being refers to what people think and how they feel 
about their life, the cognitive and affective outcomes they reach when they evaluate their existence" (Csikszentmihalyi, 2014). Ryff (1989) discussed the concept of well-being, which is fed from the eudemonic point of view, in terms of accepting the negative aspects of the individual, having life goals, showing personal development and establishing environmental relations based on values, rather than focusing only on happiness and positive aspects: Ryff (1989) talked about the individual reaching his goals with the awareness of his potential by means of self-realization. Psychological well-being is a process with six sub-dimensions: self-acceptance; individual development; environmental dominance; autonomy; positive relationships with others and life purpose (Hefferon \& Boniwell, 2018; Ryff, 1989). Self-acceptance is the acceptance of the experiences of the individual at the maturity level and the individual evaluates past and present negative experiences with positive emotions and develops positive thoughts. Individual development is the individual being open and willing to accept new life experiences, being able to see changes in himself and having a sense of struggle. Environmental domination is the individual's ability to be in an environment suitable for his own values and needs and to have control. Autonomy is the ability of the individual to make his own decisions and to have internal control with the ability of self-mastery. Positive relationships with others means that the individual establishes positive relations with others by showing empathy, building a relationship of trust and conducting relations within the framework of respect. Life purpose means that the individual uses his goals in life as motivation to determine his goals and adds meaning to his life by knowing the importance of the past and present in his life (Ryff \& Keyes, 1995; Ryff \& Singer, 2008). Csikszentmihalyi (2014) presented his main idea as "to focus on understanding how people perform at their best and what their experiences are when their business is doing well". Csikszentmihalyi (2014) regarded "to be intensely involved in every moment of the activity (physical or cognitive)" as the crucial flow, and advocated the necessity of feeding the individual with positive emotions in order to reach the flow (Hefferon \& Boniwell, 2018). Previous studies have shown that people with high psychological well-being have established positive and harmonious relationships with their environment, can cope with problems more easily, act more freely with self-confidence, have self-control, have goals and lead a life in line with a purpose, attach importance to their development and care about development. It can be seen that their emotional intelligence is higher because of this (Deniz et al., 2017; İkiz \& Asici, 2017; Ryff, 2014; Yakut \& Yakut, 2018).

The changes experienced with globalization have affected leadership approaches as well as existing psychological views, and the need to focus on people and to understand people more, and the necessity of focusing more on understanding and being understood, which is the main element of communication, have come to the fore. Examination of the relevant literature shows that the effect of authentic leadership, which provides an environment of trust, is open and clear to its followers, coincides with its values as it is, and accepts itself with its past, and organizational communication and the mediator role of individuals' psychological well-being in this effect have not been previously studied in educational organizations. Using data obtained from teachers, the purpose of this current study is to examine the effect of authentic leadership on communication in educational organizations and the mediating role of psychological well-being in this effect. The important aspect of this research is to examine the relationship between the authentic leadership behaviors of school administrators and their followers in various dimensions. It is hoped that this study will contribute to the literature. It is predicted that in the coming years, the approach of leaders in educational organizations, the communication with their followers depending on this approach, and the sensitivity of positive psychology in an organization whose principal element is human, will be discovered in educational organizations as well as in every organization.

\section{RESEARCH METHOD \\ Research Model}

The purpose of this study is to determine the mediating role of psychological well-being in the effect of authentic leadership on organizational communication. The correlation design, one of the quantitative research designs, was employed. A correlation pattern is used to find and describe the effect or relationship between two or more variables (Creswell, 2019). Baron and Kenny's (1986) four-stage model was used to test the mediation relationship: there are three variables in the model, dependent, independent and mediator. In this model, there are three conditions which must be met for the mediating effect: the effect of the independent variable on the mediating variable $(\mathrm{H} 2)$; the effect of the independent variable on the dependent variable $(\mathrm{H} 1)$; and when the effects of the mediator variable and the independent variable on the dependent variable are 
considered together, the mediating variable should have a significant effect on the effect of the independent variable on the dependent variable. In this case, we can talk about 'full mediation' if the effect disappears completely, or 'partial mediation' if there is a decrease in the effect (Baron \& Kenny, 1986; Yay et al., 2020). The hypotheses of the research and the intended theoretical model are given in Figure 1.

$\mathrm{H}_{1}$. Authentic leadership affects organizational communication.

$\mathrm{H}_{2}$. Authentic leadership affects psychological well-being.

$\mathrm{H}_{3}$. Psychological well-being affects organizational communication.

$\mathrm{H}_{4}$. Psychological well-being has a mediating role between authentic leadership and organizational communication.

\section{Population and Sample of the Research}

The universe of the research consists of teachers working in the Anatolian side of Istanbul, in the disricts of Üsküdar, Kadıköy, Beykoz, Maltepe, Sancaktepe and Pendik, in the 2020-2021 educational year. The sample was determined by the easy method and the data from 439 volunteer teachers were obtained by collecting the scales reported on Google forms on the digital platform. Of the total number of teachers, $302(68.8 \%)$ were female and $137(31.2 \%)$ were male. In terms of their years in teaching, $154(35.1 \%)$ of the teachers had between one and ten years of service; 142 (32.3\%) had 11-20 years and 143 (32.6\%) had 21 years and above. In terms of their education level, $333(75.9 \%)$ of the teachers had undergraduate and $106(24.1 \%)$ had post-graduate qualifications.

\section{Measurement Tools and Data Collection}

In this study, a personal information form, the authentic leadership scale, the communication competence scale and the psychological well-being scale were used as data collection tools. The personal information form prepared by the researcher consisted of three questions asking about the gender, the length of professional service and the educational status of the participants. The authentic leadership scale was developed by Walumbwa et al. (2008) and adapted into Turkish by Tabak et al. (2010), and validity and reliability studies were conducted to ensure its suitability. The scale consists of four sub-dimensions (self awareness, internalized moral perspective, balanced transaction and relational transparency) and sixteen items. It is a five-point Likerttype scale (1. Never, to 5. Always) and the reliability coefficient of the scale was found by Tabak et al. (2010) to be .90 . In the current study, the reliability coefficient of the scale was calculated as .95 . The communication competence scale was developed by Wiemann (1977) and adapted into Turkish by Topluer (2008). The scale consists of three sub-dimensions (understanding empathy, social comfort and supporting) and 31 items. It is also a five-point Likert-type scale (1. Never, to 5. Always). The reliability coefficient of the scale was found to be .96 by Toptaner [2008]. In the current study, the reliability coefficient of the scale was found to be .98 . The psychological well-being scale was developed by Diener et al. (2009) and adapted into Turkish by Telef (2013). The scale consists of single dimension (pyschological well-being) and eight items. It is a seven-point Likerttype scale (1. I strongly disagree, to 7. I strongly agree). The reliability coefficient of the scale was found to be .80 by Telef (2013) and in the current study it was found to be .80 . The data collection tools were applied online to the participants after permission from the Istanbul Provincial Directorate of National Education had been obtained. The acquired data were tested using regression analysis and the Sobel test was used to calculate the significance of the mediation effect.

Based on the assumption that the authentic leadership scale and the communication competency scale used in the research are equally spaced, the score interval coefficient for the arithmetical averages was calculated as 0.80 . Scoring range $=$ (highest value-lowest value) $/ 5=4 / 5=0.80$. Accordingly, the evaluation range of the arithmetical averages was as follows: 1.00-1.80 'very low' never, 1.81-2.60 'low' very rarely, 2.61-3.40 'moderate' sometimes, 3.41-4.20 'high' often, and 4.21 -5.00 'too high' all the time. Based on the assumption that the psychological well-being scale is equally spaced, the score interval coefficient for the arithmetical means was calculated as 0.86 . Between 1.00-1.86 'strongly disagree', between 1.87-2.71 'disagree', between 2.72-3.57 'somewhat disagree', between 3.58-4.43 'undecided', between 4.44-5.29 'somewhat agree', between 5.30-6.14 'agree', and between 6.15-7.00 'strongly agree'. 


\section{RESULTS AND ANALYSIS}

In this section, the findings of the research are presented. First, the results regarding whether the data were normally distributed according to the tests performed are given in Table 1 . Values between +1.5 and -1.5 are accepted as normal distribution (Tabachnick \& Fidell, 2013). In Table 1, the data can be seen to be normally distributed according to these values.

Table 1. Skewness and kurtosis values of the variables

\begin{tabular}{lrc}
\hline Variables & Skewness & Kurtosis \\
\hline 1. Authentic leadership &,- 965 &, 490 \\
2. Communication & $-1,187$ &, 766 \\
3. Psychological well-being &,- 565 &, 774 \\
\hline
\end{tabular}

Table 2. T-test results of authentic leadership, communication and psychological well-being by gender

\begin{tabular}{clllllc}
\hline Variables & Gender & $N$ & $\boldsymbol{x}^{-}$ & Ss & \multicolumn{1}{c}{$\boldsymbol{t}$} \\
& & & & & $\boldsymbol{t}$ \\
\hline Authentic & Female & 302 & 3,66 & 0,86 & $-1,95$ & \multirow{2}{*}{052} \\
leadership & Male & 137 & 3,83 & 0,89 & $-1,92$ & \\
Communication & Female & 302 & 3,85 & 0,92 & $-2,24$ & \multirow{2}{*}{025} \\
Psychological & Male & 137 & 4,06 & 0,85 & $-2,31$ & \\
well-being & Female & 302 & 5,95 & 0,60 & 1,36 & \multirow{2}{*}{172} \\
\hline
\end{tabular}

${ }^{*} \mathrm{p}<.005$

The t-test results of authentic leadership, communication and psychological well-being are given in Tables 2 and 3 after the data showed a normal distribution. Table 2 shows that there was a significant difference in the communication competencies of the teachers according to their gender. The significance and the average of communication competence is higher in the male teachers $\left(x^{-}=4.06, p<.005\right)$ than in the female teachers $(\bar{x}=3.85, \mathrm{p}<.005)$.

Table 3: T-test results of authentic leadership, communication and psychological well-being by educational background

\begin{tabular}{cllllll}
\hline Variables & \multicolumn{1}{c}{$\begin{array}{c}\text { Educational } \\
\text { Background }\end{array}$} & N & $\boldsymbol{x}^{-}$ & Ss & \\
\hline Authentic & Undergraduate & 333 & 3,71 & 0,87 &,- 292 & \multirow{2}{*}{, 770} \\
leadership & Postgraduate & 106 & 3,73 & 0,87 &,- 292 & \\
Communication & Undergraduate & 333 & 3,92 & 0,91 &,- 056 & \multirow{2}{*}{955} \\
Psychological & Postgraduate & 106 & 3,92 & 0,88 &,- 057 & \\
well-being & Undergraduate & 333 & 5,88 & 0,65 & $-2,48$ & \multirow{2}{*}{, 013} \\
\hline
\end{tabular}

${ }^{*} \mathrm{p}<.005$

In Table 3, the t-test results related to authentic leadership, communication and psychological well-being are given according to education level. These results show that psychological well-being showed a significant difference according to educational status: the psychological well-being of teachers with a postgraduate qualification $(\bar{x}=6.05, \mathrm{p}<.005)$ was more positive than that of the graduate teachers $(\bar{x}=5.88, p<.005)$.

The arithmetical mean, standard deviation and correlation coefficient values between the variables of authentic leadership, organizational communication and psychological well-being are given in Tables 4 and 5 . 
Table 4. Correlation Analysis Results

\begin{tabular}{llll}
\hline Variables & 1 & 2 & 3 \\
\hline $\begin{array}{l}\text { 1.Authentic } \\
\text { Leadership }\end{array}$ & 1 & & \\
2. Communication &, $85^{* *}$ & 1 & \\
3. Psychological &, $17^{* *}$ &, $19^{* *}$ & 1 \\
Well-being & & & \\
Mean & 3,71 & 3,92 & 5,92 \\
$\quad$ Standard & 0,87 & 0,90 & 0,63 \\
Deviation & & &
\end{tabular}

Table 4 shows that the general averages of authentic leadership perceived by the teachers were calculated as $\bar{x}=3.71$, the general averages of organizational communication were $\bar{x}=3.92$ and the general averages of psychological well-being were $\bar{x}=5.92$. According to the teachers' opinions, school administrators' authentic leadership compliance and organizational communication scores were high $(r=0.85, \mathrm{p}<.001)$, their authentic leadership and psychological well-being scores were low $(\mathrm{r}=0.17, \mathrm{p}<.001)$, and their psychological well-being scores were high $(\mathrm{r}=0.85, \mathrm{p}<.001)$. A low $(\mathrm{r}=0.19, \mathrm{p}<.001)$ and a positively significant relationship was found between the well-being and organizational communication scores. These findings support the $\mathrm{H} 1, \mathrm{H} 2$ and $\mathrm{H} 3$ hypotheses of the study.

Table 5. Descriptive Analysis Results

\begin{tabular}{lccc}
\hline Variables & $\boldsymbol{N}$ & Mean & $\begin{array}{c}\text { Standard } \\
\text { Deviation }\end{array}$ \\
\hline Relational transparency & 439 & 3,80 & 0,88 \\
\hline Internalized moral perspective & 439 & 3,79 & 0,93 \\
\hline Balanced transaction & 439 & 3,54 & 1,03 \\
\hline Self-awareness & 439 & 3,65 & 1,00 \\
\hline Authentic leadership total & 439 & 3,71 & 0,87 \\
\hline Understanding and empathy & 439 & 3,94 & 0,97 \\
\hline Social comfort & 439 & 3,86 & 0,84 \\
\hline Supporting & 439 & 3,93 & 0,97 \\
\hline Communication competence total & 439 & 3,92 & 0,90 \\
\hline Psychological well-being total & 439 & 5,92 & 0,63 \\
\hline
\end{tabular}

Table 5 shows the average values of the four sub-dimensions of authentic leadership: transparency in relationships was $\bar{x}=3.80$; internalized morality was $\bar{x}=3.79$; balanced evaluation of knowledge was found to be $\bar{x}=3.54$ and self-awareness was $\bar{x}=3.65$. The mean values of the three sub-dimensions of communication competence were understanding and empathy $\bar{x}=3.94$; social comfort $\bar{x}=3.86$ and support $x=3.93$.

The results of Baron and Kenny's (1986) four-stage regression analysis model used for testing the hypotheses are given in Tables 6 and 7 . 
Table 6. Regression Analysis

\begin{tabular}{|c|c|c|c|c|c|c|}
\hline \multicolumn{7}{|l|}{ Hypothesis 1} \\
\hline Independent variable & Dependent variable & $\beta$ & $R^{2}$ & & $t g$ & Si \\
\hline \multirow{2}{*}{ Authentic leadership } & \multirow{2}{*}{ Communication } & \multirow{2}{*}{$\underline{.855}$} & \multirow{2}{*}{.730} & & 34,3 & .0 \\
\hline & & & & 99 & 00 & \\
\hline \multicolumn{7}{|l|}{ Hypothesis 2} \\
\hline Independent variable & $\begin{array}{l}\text { Mediator/dependent } \\
\text { variable }\end{array}$ & $\beta$ & $R^{2}$ & & $t^{t}$ & Si \\
\hline \multirow{2}{*}{ Authentic leadership } & Psychological & \multirow{2}{*}{.178} & \multirow{2}{*}{.032} & \multicolumn{2}{|r|}{3,77} & .0 \\
\hline & well-being & & & 3 & 00 & \\
\hline \multicolumn{7}{|l|}{ Hypothesis 3} \\
\hline $\begin{array}{l}\text { Mediator/independent } \\
\text { variable }\end{array}$ & Dependent variable & $\beta$ & $R^{2}$ & \multicolumn{3}{|c|}{$t g$} \\
\hline \multirow{2}{*}{$\begin{array}{l}\text { Psychological } \\
\text { being }\end{array}$} & \multirow{2}{*}{ Communication } & \multirow{2}{*}{.193} & \multirow{2}{*}{.037} & & 4,12 & .0 \\
\hline & & & & 0 & 00 & \\
\hline
\end{tabular}

In the first stage of the regression analysis carried out according to this model, it was found that authentic leadership, which was the independent variable, explained the dependent variable, organizational communication, by $73 \%$, and authentic leadership had a positive and significant effect on organizational communication $(\beta=.855, p<.001)$. In the second stage, it was found that authentic leadership, which was the independent variable, explained the mediating variable psychological well-being by $3 \%$, and that authentic leadership had a significant positive effect on psychological well-being $(\beta=.178, p<.001)$. In the third stage, it was found that psychological well-being, which was the independent variable, explained organizational communication by $4 \%$ and psychological well-being had a significant positive effect on organizational communication $(\beta=.193, \mathrm{p}<.001)$.

Table 7. Regression Analysis

\begin{tabular}{|c|c|c|c|c|c|c|}
\hline Hypothesis 4 & & & & & & \\
\hline $\begin{array}{l}\text { Independent/ } \\
\text { Mediator Variable }\end{array}$ & $\begin{array}{l}\text { Dependent } \\
\text { Variable }\end{array}$ & $\beta$ & $R^{2}$ & $t$ & Sig. & $\begin{array}{l}\text { Sobel } \\
(z) / \text { Sig. }\end{array}$ \\
\hline Authentic leadership & Communication & .847 & .732 & 33,623 & .000 & $4.0859 / 0.000$ \\
\hline Psychological well-being & & .043 & & 1,704 & .089 & \\
\hline
\end{tabular}

In the fourth and final stage, the effects of authentic leadership, which was the independent variable, and psychological well-being, which was the mediating variable, on organizational communication were evaluated together and it was found that authentic leadership $(\beta=.847, \mathrm{p}<.001)$ and psychological well-being $(\beta=.043, \mathrm{p}<.001)$ had a positive and significant effect on organizational communication. However, the effect of authentic leadership on organizational communication ( $\beta$ value) was .855 when calculated alone. When the mediator variable was calculated with psychological well-being, it decreased to .847 . This difference is explained by the fact that psychological well-being plays a partial mediating role in the positive and significant effect of authentic leadership on organizational communication. With the Sobel test, the mediating effect was found to be significant and the test result (Sobel $(\mathrm{z})=4.059, \mathrm{p}<.001$ ) was significant. This finding supports the H4 hypothesis. 


\section{DISCUSSION, CONCLUSION AND SUGGESTIONS}

In this study, the relationship pattern between authentic leadership, organizational communication and psychological well-being in schools was examined according to the views of teachers. In the t-test results of the teachers according to their gender, the opinions of the school administrators on the communication competencies showed that the male teachers were higher than the female teachers. These results confirm those of Sağar and Parlak (2018), Demirkaya (2012) and Çelik (2013). Unlike the results of those studies, Bala (2017), Uzman (2019) and Çağlar and Çınar (2021) did not find a significant difference by gender. Considering the results of the current study, it can be said that female teachers' perceptions of their school administrators had a more sensitive perspective on communication skills and competencies.

In this study, according to the t-test results of the teachers' educational status, the psychological wellbeing of undergraduate teachers was lower than that of graduate teachers. Jeon et al. (2018) reported similar results, but the most common results in the literature are that there is no significant difference between the educational status of teachers and their psychological well-being (Altiparmak, 2019; Dinç, 2018; Ertürk et al., 2016; Köylü \& Gündüz, 2019). Considering the results of this current study, it can be said that the postgraduate teachers' self-confidence, their greater awareness of their life goals and their personal development all had an effect.

The most striking finding of the study is that authentic leadership highly affects organizational communication. Jiang and Men (2017) found that authentic leadership significantly and positively affects communication; Lee et al. (2018) concluded that authentic leadership has a significant impact on internal communication and Basit and Siddigui (2020) found that authentic leadership has a significant effect on communication. All these findings coincide with the results of the current study and the H1 hypothesis was accepted. The characteristics of an authentic leader of establishing transparent, open and honest relationships and bringing trust and binding elements in to the organization can be considered as an important factor in the high impact of the research. It can also be said that the power of communication within an organization is directly proportional to the leader's authentic leadership characteristics.

In the second step of the study, a positive and significant effect was found in the effect of authentic leadership on psychological well-being. It can be said that authentic leadership has a basis which will reveal a positive leadership style. Authentic leaders provide transparent leadership with their moral, ethical, truthful and righteous characteristics. Hülsheger and Schewe (2011) found that the individual well-being of leaders decreased when they displayed false emotions and behaviors. The fact that the natural and sincere relationships established by authentic leaders have a positive effect on their own psychological well-being coincides with the $\mathrm{H} 2$ hypothesis of this research, and results confirmed those of Weiss et al. (2018) and Yener (2018).

In the third step of the study, it was determined that psychological well-being had a positive and significant effect on organizational communication. This result confirms those of Jiang and Men (2017), Di Fabio (2017), Behzadi et al. (2020) and Mahmoudi et al. (2020). Psychological well-being is a concept which looks at the evaluation of individuals' mentality and life from a wide perspective and the positive effect of communication within an organization on the well-being of individuals confirms the H3 hypothesis. The high well-being of the individual is also an indicator of positive communication within the organization.

According to the results of the regression analysis in the final stage of the study, it was determined that psychological well-being had a partial mediating role in the significant positive effect of authentic leadership on organizational communication. When the third and fourth stages of the model test are compared, it can be seen that the $\beta$ value decreased from 8.55 to 8.47 . It can be said that this is a significant effect. The reasons why the difference between the two values is low are that psychological well-being is at the core of authentic leadership characteristics, and that in the positive psychology-based authentic leadership there is selfknowledge with transparent communication and the individual's awareness of meaningful, valuable and contented feelings in terms of evaluating his life.

The results show that authentic leadership significantly affects organizational communication. The subdimensions of authentic leadership (self-acceptance, self-awareness, transparency, honesty and moral and ethical high perception levels) are based on positive psychology. The reflection of this also brings about the well-being of the individual. An individual's knowing himself and being at peace with himself (in his past and 
future goals) will also affect his communication with those around him. Communication within the organization will also be affected by the leadership characteristics of the leader. An environment of trust within an organization is a primary dimension which affects communication: this is a feature of an authentic leader which also exists in an individual with psychological well-being. The communication between people within an organization will also affect their work performance and the steps needed to reach the goals of the organization.

In the light of the results reported above, it is thought that the higher the authentic leadership characteristics of school leaders, the higher (and therefore the more effective) the communication will be within the school. It is therefore recommended that administrators working in educational organizations should make self-evaluations by knowing their authentic leadership characteristics in order to have a better communication with the organization. Educational administrators should aim to exhibit appropriate behaviors by knowing their managerial competencies and characteristics in order to be successful in their goals and objectives. They can follow academic studies on these subjects, receive support for their personal development and focus on their own strengths and weaknesses. The communication of administrators with teachers is very important. In this regard, the effects of other leadership styles on communication could be further studied with different variables. Managers have a responsibility to have self-awareness and to contribute to their own development in this direction. At the same time, the Turkish Ministry of National Education (MEB) should provide training to school administrators which includes the leadership skills which will maintain strong and effective communication. Because this study was carried out with teachers's perceptions of their school administrators as the participants, more in-depth research could be done with school administrators and in a mixed study in order to examine the issue from different perspectives. The effect of school administrators ' leadership styles on organizational communication could also be studied using different mediator variables and could contribute to improving the communication skills of managers.

\section{REFERENCES}

Aksoy, C. (2020). Liderlik kavramına genel bir bakış. In H.T. Uysal, C. Aksoy, \& F. Yılmaz, (Eds.), Liderlik Tarzları: Çağdaş yönetim yaklaşımıyla insan sanatında ustalaşma (pp.1-16). Nobel Akademik Publishing.

Akyürek, M. İ. (2020). Otantik liderlik: Bir alanyazın taraması. International Journal of Leadership Studies 3(2), (99-109).

Altiparmak, D. (2019). Öğretmenlerin yaşam amacı ve anlamı düzeyleri ve iyi oluşları arasındaki ilişkideöz-duyarlık değişkeninin aracı rolü. [Postgraduate thesis]. İstanbul Sabahattin Zaim University.

Avolio, B. J., \& Gardner, W. L. (2005). Authentic leadership development: getting to the root of positive forms of leadership. The Leadership Quarterly, 16, 315-338.http://doi.org:/10.1016/j.leaqua.2005.03.001

Avolio, B. J., Gardner, W. L., Walumbwa, F. O., Luthans, F., \& May, D. R. (2004). Unlocking the mask: Alook at the process by which authentic leaders impact follower attitudes and behaviors. The Leadership Quarterly, 15, 801-823.http://doi.org:/10.1016/j.leaqua.2004.09.003

Ayeni, A. J., \& Akınola, O. B. (2020). Organizational communication and teacher's productivity in secondary schools in Ondo State, Nigeria. Journal of Education and Practice, 11(17), 94-102. http://doi.org:/10.7176/JEP/11-17-11

Ayeni, A. J., \& Akinfolarin, C. A. (2014). Assessing principals' coordinating and controlling strategies for effective teaching and quality learning outcome in secondary schools in Ondo State, Nigeria. International Journal of Learning, Teaching and Educational Research, 7(1), 180-200.

Aziz, A., \& Dicle, Ü. (2017). Örgütsel iletişim. Hiper Publishing.

Bala, H. F. (2019). Ortaöğretim öğretmenlerinin eğitim yöneticilerinin iletişim becerilerine ilişkin algıları: Denizli Illi Acıpayam İlçe örneği [Non-thesis master's program project]. Pamukkale University.

Baron, R. M., \& Kenny, D. A. (1986). The moderator-mediator variable distinction in social psychological research: conceptual, strategic and statistical considerations. Journal of Personality and Social Psychology, 51(6), 1173-1182.

Basit, A., \& Siddiqui, D. A. (2020). Authentic leadership and openness to change in Pakistani service industry: The mediating role of trust and transparent communication. International Journal of Human Resource Studies, 10(3), 291-341.http://dx.doi.org/10.2139/ssrn.3757483 
Baykal, E. (2017). Otantik liderlik ve pozitif çıktıları: Pozitif örgütsel davranış bakış açısı. International Journal of Economics and Administrative Sciences 3(3), (42-64). http://doi.org/10.47542/sauled.807122

Behzadi, S., Koochakzadeh, R. S., \& Sedaghat, S. (2020). The model of organizational culture with psychological well-being with mediating of communication skills. Iranian Journal of Educational Sociology, 3(4), 161-169. http://doi.org/10.52547/ijes.3.4.161

Bursalığlu, Z. (2019). Okul yönetiminde yeni yapıve davranış (20th ed.). Pegem Publishing.

Büyükbeşe, T., Çavuşoğlu, S., \& Okun, O. (2019). Otantik liderlik ile örgütsel bağlllık arasında psikolojik sermayenin aracılık rolü: Bingöl Üniversitesi örneği. International Journal of Society Studies, 10(17), 194-225. http://doi.org/10.18506/anemon.645661

Carr, A. (2016). Pozitif psikoloji (Ü. Şendilek, Trans.). Kaknüs Publishing.

Coşar, S., Tabak, A., \& Polat, M. (2012). Otantik liderlik. In A. Tabak, H. Şeşen \& T. Türköz (Eds.), Liderlikte güncel yaklaşımlar ve uygulamada kullanılabilecek ölçekler (pp.193-226). Detay Publishing.

Creswell, J. W. (2019). Eğitim Araştırmaları (2nd ed.). Edam Yayıncılık.

Csikszentmihalyi, M. (2014). Flow and the foundations of positive psychology. Springer.

Cüceloğlu, D. (2021). 'Mış gibi” yaşamlar (21st ed.). Remzi Kitabevi.

Cüceloğlu, D. (2021). İletişim donanımları (63rd ed.). Remzi Kitabevi.

Çağlar, Ç., \& Çınar, H. (2021). Okul müdürlerinin iletişim yeterliliklerinin öğretmenlerin örgütsel bağlllı̆̆1 üzerindeki etkisi. E- International Journal of Educational Research, 12(1), 157-170. http://doi.org/10.19160/ijer.831956

Çelik, M. (2013). İstanbul ili Arnavutköy ilçesindeki ortaöğretim kurumlarında görev yapan yöneticilerin iletişim becerilerinin öğretmen motivasyonları ve akademik tükenmişlikleri üzerine etkisi. [Postgraduate thesis]. Yeditepe University.

Demirci, İ., \& Şar, A. H. (2017). Kendini bilme ve psikolojik iyi oluş arasındaki ilişkinin incelenmesi. Journal of Human and Social Sciences Research, 6(5), 2710-2728.

Demirkaya, Y. (2012). Okul müdürlerinin çatışma yönetimi stratejileri ve iletişim tarzlarına yöneliköğretmen algıları. [Postgraduate thesis]. Mehmet Akif Ersoy University.

Deniz, M. E., Erus, S. M., \& Büyükcebeci, A. (2017). Bilinçli farkındalık ile psikolojik iyi oluş ilişkisinde duygusal zekanın aracilık rolü. Turkish Journal of Psychological Counseling and Guidance, 7(47), 17-31.

Di Fabio, A. (2017). Positive healthy organizations: promoting well-being, meaningfulness and sustainability in organizations. Frontiers in Psychology, 8, 1938. http://doi.org/10.3389/fpsyg.2017.01938

Dienar, E., Diener, M. \& Diener, C. (2009). Factors Predicting the Subjective Well-Being of Nations. Journal of Personality and Social Psychology, 69 (5), 851-864.

Dinç, G. (2018). Özel eğitim kurumlarında çalı̧̧an özel eğitim öğretmenlerinin mesleki tükenmişlik düzeyleri ile öznel iyi oluş düzeylerinin incelenmesi. [Postgraduate thesis]. Biruni University.

Eagly, A. H. (2005). Achieving relational authenticity in leadership: Does gender matter? The Leadership Quarterly, 16, 459-474.https://doi.org/10.1016/j.leaqua.2005.03.007

Elrehail, H., Emeagwali, O. L., Alsaad, A., \& Alzghoul, A. (2018). The impact of transformational and authentic leadership on innovation in higher education: The contingent role of knowledge sharing. Telematics and Informatics, 35, 55-67. https://doi.org/10.1016/j.tele.2017.09.018

Ertekin, İ. (2017). Örgütsel iletişim. Gece Kitaplı̆̆ı.

Ertürk, A., Keskinkılıç Kara, S. B., \& Zafer Güneş, D. (2016). Duygusal emek ve psikolojik iyi oluş: Bir yordayıcı olarak yönetsel destek algisı. Abant İzzet Baysal University Journal of the Faculty of Education, 16(4), 17231744.

Eskiyörük, D. (2015). Örgütsel iletişim. Cinius Publishing.

Gardner, W. L., Avolio, B. J., \& Walumbwa, F. O. (2005). Authentic leadership development: Emergent trends and future directions. In Authentic leadership theory and practice: Origins, effects and development (pp.387406). Emerald Group Publishing.

Gardner, W. L., Avolio, B. J., Luthans, F., May, D. R., \& Walumbwa, F. (2005). Can you see the real me? A selfbased model of authentic leader and follower development. The Leadership Quarterly, 16, 343-372. https://doi.org/10.1016/j.leaqua.2005.03.003 
Gardner, W. L., Cogliser, C. C., Davis, K. M., \& Dickens, M. P. (2011). Authentic leadership: A review of the literature and research agenda. The Leadership Quarterly, 22, 1120-1145. https://doi.org/10.1016/j.leaqua.2011.09.007

Goffee, R., \& Jones, G. (2005). Managing Authenticity: The paradox of great leadership. Harvard Business Review, 87-94.

Goleman, D. (2004). What makes a leader? Harvard Business Review.

Göçen, A. (2019). Öğretmenlerin yaşam anlamı, psikolojik sermaye ve cinsiyetinin psikolojik iyi oluşlarına etkisi. Cumhuriyet International Journal of Education, 8(1), 135-153.https://dx.doi.org/10.30703/cije.457977

Güçlü, M. (2017). Örgütsel iletişim: Eğitim kurumlarındaki yeri ve önemi açısından bir değerlendirme. International Journal of Society Studies, 7(13), 855-870.https://doi.org/10.26466/opus.350484

Gülver, M. (2014). Örgütsel iletişim ve ast-üst ilişkileri. In Harmancı, F. M., Gözübenli, M. \& Alaç, A.E. (Eds.), Güvenlik sektöründe insan ilişkileri (pp. 25-44). Nobel Akademik Publishing.

Hefferon, K., \& Boniwell, I. (2018). Pozitif psikoloji kuram, araştırma ve uygulamalar (T. Doğan, Trans.). Nobel Akademik Publishing (Print date of the original work, 2011).

Hülsheger, U. R., \& Schewe, A. F. (2011). On the costs and benefits of emotional labor: A meta-analysis of three decades of research. Journal of Occupational Health Psychology, 16(3), 361-389. https://doi.org/10.1037/a0022876

Işık, Ş. (2020). Karakter gü̈cleri ve erdemler. Pegem Publishing.

İkiz, F. E., \& Asıc1, E. (2017). The relationship between individual innovativeness and psychological wellbeing: The example of Turkish counselor trainees. International Journal of Progressive Education, 13(1), 5263.

Jeon, L., Buettner, C. K., \& Grant, A. A. (2018). Early childhood teachers' psychological well-being: Exploring potential predictors of depression, stress and emotional exhaustion. Early Education and Development, 29(1), 53-69. https://doi.org/10.1080/10409289.2017.1341806

Jiang, H., \& Men, R. L. (2017). Creating an engaged workforce: The impact of authentic leadership, transparent organizational communication, and work-life enrichment. Communication Research, 44(2), 225-243. https://doi.org/10.1177/0093650215613137

Karadağ, E., \& Özetkin-Bayır, Ö. (2018). The effect of authentic leadership on school culture: A structural equation model. International Journal of Educational Leadership and Management, 6(1), 40-75. https://dx.doi.org/10.17583/ijelm.2018.2858

Kernis, M. H. (2003). Toward a conceptualization of optimal self-esteem. Psychological Inquiry, 14(19), 1-26. https://doi.org/10.1207/S15327965PLI1401_01

Keyes, C. L., Shmotkin, D., \& Ryff, C. D. (2002). Optimizing well-being: The empirical encounter of two traditions. Journal of Personality and Social Psychology, 82(6), 1007-1022.

Koçel, T. (2018). İşletme yöneticiliği (17th ed.). Beta Pbunlishing.

Korkmaz, O. (2017). Otantik liderlik ve örgütsel güven. The Journal of Academic Social Science Studies, 58, 437454. https://doi.org/10.9761/JASSS7131

Köylü, D., \& Gündüz, Y. (2019). Öğretmenlerin karar alma sürecine katıllım düzeylerinin örgütsel bağlllık ve psikolojik iyi oluş ile ilişkisi. Ufuk Üniversitesi Sosyal Bilimler Enstitüsü Dergisi, 15, 279-299.

Ladkin, D., \& Spiller, C. (2013). Reflections on authentic leadership: Clashes, convergences and coalescences. Edward Elgar Press.

Lee, S. C., Choi, K., \& Jang, H. Y. (2018). The role of organizational communication and hope between authentic leadership and job satisfaction. International Journal of Pure and Applied Mathematics, 120(6), 5777-5792.

Luthans, F., \& Avolio, B. (2003). Authentic leadership. R. E. Quinn, J. E. Dutton, K. S. Cameron, Positive Organizational Scholarship: Foundations of a new discipline içinde, [e-book].

Luthans, F., Avolio, B. J., Avey, J. B., \& Norman, S. M. (2007). Positive psychological capital: Measurement and relationship with performance and satisfaction. Personnel Psychology, 60, 541-572.

Mahmoudi Eshkaftki, F., Ghazanfari, A., \& Solati, S. K. (2020). Effectiveness of social and communication skills training using cognitive-behavioral approach on psycgological well-being and happiness of female 
students with martyred and veteran parents in Shahrekord, Iran, Governmental Universities. Iranian Journal of War and Public Health, 12(2), 85-91. https://doi.org/10.29252/ijwph.12.2.85

Maxwell, J. C. (2020). Liderlikyasaları (8th ed.). Beyaz Publishing.

Northouse, P. G. (2018). Leadership (8th ed.). SAGE Publications.

Oruç, Ü. E. (2020). Otantik liderlik. In H.T. Uysal, C. Aksoy ve F. Yılmaz(Ed.), Liderlik tarzları: Çağdaş yönetim yaklaşımıyla insan sanatında ustalaşma (pp.331-376). Nobel Akademik Publishing.

Peterson, C. (2006). A pimer in positive psychology. Oxford University Press.

Reza, H. K., \& Nugroho, S. H. (2020). The influence of organizational communication and leadership factors on the performance of employee. Sttal Postgraduate- International Conference, 4(1).

Robbins, S. P., \& Judge, T. A. (2019). Örgütsel davranış (14th ed.). (İ. Erdem, Trans.). Nobel Akademik Yayıncilık (Original work published in 2019, 14th ed.).

Ryff, C. D. (1989). Happiness is everything, or is it? Explorations on the meaning of psychological well-being. Journal of Personality and Social Psychology, 57 (6), 1069-1081.

Ryff, C. D. (2014). Psychological well-being revisited: Advances in the science and practice of eudaimonia. Psychother Psychosom, 83, 10-28. https://doi.org/10.1159/000353263

Ryff, C. D., \& Keyes, C. L. M. (1995). The structure of psychological well-being revisited. Journal of Personality and Social Psychology, 69 (4), 719-727.https://doi.org/10.1037/0022-3514.69.4.719

Ryff, C. D., \& Singer, B. H. (2008). Know thyself and become what you are: A eudaimonic approach to psychological well-being. Journal of Happiness Studies, 9, 13-39.

https://doi.org/10.1007/s10902-006-9019-0

Sağır, M. \& Parlak, F. (2018). Okul Yöneticilerinin İletişim Becerileri ile Örgütsel Güven Arasındaki İlişki. Ekev Akademi Dergisi, 22(76), 165-185.

Seligman, M. E. P., \& Csikszentmihalyi, M. (2000). Positive psychology. American Psychologist, 55(1), 5-14.

Shamir, B., \& Eilam, G. (2005). What's your story? A life-stories approach to authentic leadership development. The Leadership Quarterly, 16, 395-417.

Soylu, Ü. (2018). Otantik liderlikve psikolojik sermaye ilişkisi: Gaziantep'te bir alan çalışması [Postgraduate thesis]. Hasan Kalyoncu University.

Sparrowe, T. (2005). Authentic leadership and the narrative self. The Leadership Quarterly, 16, 419-439.

Tabachnick, B. G., \& Fidell, L. S. (2013). Using multivariate statistics (6th ed.). Pearson Publishing.

Tabak, A., Sığrı, Ü., Arlı, Ö. \& Coşar, S. (2010). Otantik liderlik ölçeğinin uyarlama çalışması (pp. 699-706). 18. Yönetim ve Organizasyon Kongresi Kongre Bildiriler Kitabı, Adana.

Tampubolon, M., \& Harati, R. (2019). Role of organizational culture, communication and leadership style on job satisfaction. International Journal of Research In Business and Social Science, 8(5), 308-315. https://doi.org/10.20525/ijrbs.v8i5.494

Telef, B. B. (2013). Psikolojik İyi Oluş Ölçeği: Türkçe'ye Uyarlama, Geçerlik ve Güvenirlik Çalışması. Hacettepe Üniversitesi Ĕ̆itim Fakültesi Dergisi, 28(3), 374-384.

Topluer, A. (2008). İlköğretim okulu yöneticilerinin iletişim yeterlilikleri ile örgütsel çatışma düzeyi arasındaki ilişki "Malatya ili örneği". [Postgraduate thesis]. İnönü University.

Uslu, E. (2017). Otantik liderlik ile iş tatmini arasındaki ilişkinin incelenmesi: Çalışanların kişilik özelliklerinin düzenleyici etkisi [Postgraduate thesis]. Hacettepe University.

Uyar, M. (2019). Beliren yetişkinlik dönemindeki bireylerin psikolojik iyi oluş düzeylerini yordamada bağlanma tarzları ve bilişsel duygu düzenlemenin rolünün incelenmesi [Print date of the original work]. Maltepe Univesity.

Uzman, Z. (2019). Ilkokul yöneticilerinin algılanan iletişim becerileri ile sını öğretmenlerinin örgütsel sessizlik düzeyleri arasındaki ilişki [Print date of the original work]. Maltepe University.

Walumbwa, F. O., Avolio, B. J., Gardner, W. L. Wernsing, T. S., \& Peterson, S. J. (2008). Authentic leadership: Development validation of a theory-based measure. Journal of Management, 34(1), 89-126. https://doi.org/10.1177/0149206307308913

Walumbwa, F. O., Wang, P., Wang, H., Schaubroeck, J., \& Avolio, B. J. (2010). Retracted:Psychological processes linking authentic leadership to follower behaviors. The Leadership Quarterly, 21, 901-914. https://doi.org/10.1016/j.leaqua.2010.07.015 
Weiss, M., Razinskas, S., Backmann, J., \& Hoegl, M. (2018). Authentic leadership and leaders' mental wellbeing: An experience sampling study. The Leadership Quarterly, 29, 309-321. https://doi.org/10.1016/j.leaqua.2017.05.007

Wiemann; J. M. (1977). Explication and test of a model of communicative competence. Human Communication Research, 3, 195-213.https://doi.org/10.1111/j.1468-2958.1977.tb00518.x

Wijewantha, P. (2018). Emphatic listening in organizational communication: Putting oneself in the other person's shoe. In S. Misiak-Kwit ve M. Wiscicka-Fernando, Communication, relations, management (pp.31) içinde. Printing House and Publishing.

Yakut, S., \& Yakut, İ. (2018). Öğretmenlerde psikolojik iyi oluş ve iş yerinde dişlanma ilişkisi. Turkish Studies, 13(18), 1357-1376.https://dx.doi.org/10.7827/TurkishStudies.13883

Yaşbay, H. (2011). Otantik liderlikve örgütsel bağhllıkilişkisi [Postgraduate thesis]. Dokuz Eylül University.

Yay, M., Fındıklı, M., \& Köse, A. M. (2020). İş değerleri ve iş tatmini ilişkisinde lider üye etkileşiminin ardışık arac1lık modeli. İstanbul Ticaret Üniversitesi Sosyal Bilimler Dergisi, 19(37), 1-26.

Yener, S. (2018). Psikolojik rahatlık algısının otantik liderliğin sinizmin üzerindeki etkisinde aracı rolü. Eskişehir Osmangazi Üniversitesi İ̈BF Dergisi, 13(1), 1-14.

Yetgin, M. A. (2020). Otantik liderlik. Akademisyen Publishing.

Yıldız, P. (2019). Örgütsel bağlllık üzerinde örgütsel güven ve örgütsel iletişimin etkisini belirlemeye yönelik bir araştırma [Postgraduate thesis]. Marmara University.

Yılmaz, F. (2020). Liderlikle ilgili temel teoriler. In H.T. Uysal, C. Aksoy ve F. Yilmaz, (Ed.), Liderlik tarzları: Çă̆daş yönetim yaklaşımıyla insan sanatında ustalaşma (pp.17-40). Nobel Akademik Publishing.

Yukl, G. (2018). Örgütlerde liderlik (8th ed.). (Ş. Çetin ve R. Baltacl, Trans.). Nobel Akademik Publishing (Print date of the original work, 2013,8th ed.).

Zel, U. (2011). Kişilik ve liderlik: Evrensel boyutlarıyla yönetsel açıdan araştırmalar, teoriler ve yorumlar (3rd ed.). Nobel Akademik Publishing.

Zıllığlu, M. (2014). Illetişim nedir? Cem Publishing. 